\title{
THE EFFECT OF THIRD PARTY FUNDS ON FINANCING IN PT. VICTORIA SHARIA BANK
}

\author{
Marahombang Rambe ${ }^{1}$, Abdul Nasser Hasibuan ${ }^{2}$, Muhammad Wandisyah ${ }^{3}$, Idris Saleh ${ }^{4}$ \\ ${ }^{1}$ IAIN Padangsidimpuan (Perbankan Syariah, FEBI, IAIN Padangsidimpuan) \\ ${ }^{2}$ IAIN Padangsidimpuan (Perbankan Syariah, FEBI, IAIN Padangsidimpuan) \\ ${ }^{3}$ IAIN Padangsidimpuan (Perbankan Syariah, FEBI, IAIN Padangsidimpuan) \\ ${ }^{4}$ IAIN Padangsidimpuan (Perbankan Syariah, FEBI, IAIN Padangsidimpuan) \\ marahombang@gmail.com ${ }^{1}$, abdulnasserhasibuan@iain-padangsidimpuan.ac.id ${ }^{2}$, \\ ${\text { muhammadwandisyah@iain-padangsidimpuan.ac.id }{ }^{3}}_{\text {idrissaleh@iain-padangsidimpuan.ac.id }}{ }^{4}$
}

\begin{abstract}
ABSTRAK
Penelitian ini dilatarbelakangi oleh pembiayaan yang menjadi salah satu kegiatan utama Bank Victoria Syariah menjalankan usahanya, dimana berdasarkan laporan keuangan publikasi PT. Bank Victoria Syariah perkembangan pembiayaan tidak sejalan dengan perkembangan dana pihak ketiga. Fenomena yang terjadi dalam penelitian ini dilihat dari penurunan dan peningkatan pada dana pihak ketiga tidak sesuai dengan penurunan dan peningkatan yang terjadi pada pembiayaan. Adapun tujuan penelitian ini untuk mengetahui "Pengaruh dana pihak ketiga terhadap pembiayaan pada PT. Bank Victoria Syariah pada tahun 2016-2018". Jenis penelitian ini adalah penelitian kuantitatif, dengan sumber data yang digunakan adalah data sekunder dalam bentuk time series dari tahun 2016-2018 sebanyak 36 sampel. Data diperoleh melalui situs Bank Victoria Syariah dan Ojk. Analisis data yang digunakan adalah analis statistik deskriptif, uji normalitas, analisis regresi linier sederhana, uji determinasi (R2), uji hipotesis (uji t), dengan data diolah menggunakan perhitungan statistik SPSS Versi 23. Hasil penelitian dengan uji koefisien determinasi (R2) persentase sumbangan pengaruh variabel dana pihak ketiga terhadap pembiayaan adalah sebesar $58,8 \%$. Sedangkan sisanya sebesar $41,2 \%$ yang dipengaruhi oleh variabel lain yang tidak ada dalam penelitian ini. Secara parsial (uji t) menunjukkan bahwa dana pihak ketiga berpengaruh secara signitifikan terhadap pembiayaan pada PT. Bank Victoria Syariah pada Tahun 2016-2018.
\end{abstract}

Kata Kunci: Dana Pihak Ketiga, Pembiayaan

\section{ABSTRACT}

This research is motivated by financing which is one of the main activities of the Islamic bank Victoria running its business, which based on the published financial statements of PT.Bank Victoria published financial statements of PT.Bank Victoria Syariah financing development is not in line with the development of third party fuds. The phenomenon that occurs in this study is seen from the decline and increase in third-party funds is not in accordance with the decrease and increase in financing. The purpose of this study was to determine the effect of third party funds on financing at PT Bank Victoria Syariah in 20162018. This type of research is quantitative research, with the source of data used is secondary data in the form of time series from 2016-2018 as many as 36 samples. Data was obtained through the Bank Victoria Syariah and Ojk website. Data analysis, normality test, simple regression analysis, detremination test (R2), hypothesis test (test $t$ ), with data processed 
using SPSS Version 23 statistical calculations. The results of the study with the coefficient determination test the percentage contribution of the influence of variable third party funds to financing is $58.8 \%$. While the remaining $41.2 \%$ is in this study. Partially ( $t$ test) shows that third party funds significantly influence the financing of PT Bank Victoria Syariah in 20162018.

Keywords: Third party funds, financing

\section{A. PENDAHULUAN}

Perkembangan dunia perbankan
semakin pesat dan mendominasi perkembangan ekonomi dan bisnis suatu Negara, baik dari segi produk, kualitas pelayanan, dan teknologi yang dimiliki. Bahkan aktifitas dan keberadaan perbankan sangat menentukan kemajuan suatu Negara dalam bidang ekonomi. Perbankan merupakan salah satu badan usaha yang bergerak dalam bidang penghimpunan dan penyaluran dana. Perbankan atau biasa disebut dengan bank menyediakan jasa keuangan bagi seluruh lapisan masyarakat. Salah satu kegiatan usaha yang paling dominan dan sangat dibutuhkan adalah kegiatan usaha lembaga keuangan perbankan. Secara umum perbankan adalah lembaga yang melaksanakan tiga fungsi utama, yaitu penghimpun dana, penyaluran dana, dan memberikan jasa bagi kelancaran lalu lintas dan peredaran uang.

Sumber dana merupakan hal terpenting untuk dapat meningkatkan jumlah pembiayaan yang akan disalurkan kepada masyarakat. Dalam menyalurkan dananya kepada nasabah, secara garis besar produk pembiayaan syariah terbagi dalam empat kategori yang dibedakan berdasakan tujuan penggunaannya yaitu: pembiayan dengan prinsip jual-beli, pembiayaan dengan prinsip sewa, pembiayaan dengan prinsip bagi hasil, dan pembiayaan dengan akad pelengkap.Dukungan penuh dari perusahaan induk PT. Bank Victoria International Tbk telah membantu tumbuh berkembang. Bank Victoria Syariah yang selalu terus berkomitmen untuk membangun kepercayaan nasabah dan masyarakat melalui pelayanan dan penawaran produk yang sesuai dengan prinsip-prinsip syariah serta memenuhi kebutuhan nasabah.Berikut ini merupakan data Dana Pihak Ketiga dan Pembiayaan berdasarkan laporan keuangan PT. Bank Victoria Syariah pada tahun 2016-2018 yang peneliti peroleh dari www. ojk.go id.

Jumlah Dana Pihak Ketiga dan Pembiayaan Pada PT. Bank Victoria Syariah tahun 2016-2018

\begin{tabular}{|c|c|c|}
\hline Tahun & $\begin{array}{c}\text { DPK (Juta } \\
\text { Rupiah) }\end{array}$ & $\begin{array}{c}\text { Pembiayaan } \\
\text { (Juta Rupiah) }\end{array}$ \\
\hline 2016 & 1.204 .591 & 952.923 \\
\hline 2017 & 1.511 .159 & 937.295 \\
\hline 2018 & 1.491 .442 & 991.010 \\
\hline
\end{tabular}

Sumber: www.ojk.go.id 
Pada tabel I.1 di atas dapat disimpulkan pada tahun 2016, dana pihak ketiga sebesar Rp. 1.204.591.000.000, sedangkan pembiayaan pada tahun yang sama Rp. 952.923.000.000. Kemudian pada tahaun 2017 dana pihak ketiga meningkat sebesar 25,44 \% menjadi Rp. 306.568.000.000, akan tetapi pembiayaan mengalami penurunan sebesar $1,64 \%$ menjadi Rp. 15.628.000.000. Kemudian pada tahun 2018 dana pihak ketiga menurun sebesar 1,30 \% menajdi Rp. 19.717.000.000, akan tetapi pembiayaan mengalami peningkatan sebesar 5,73\% menjadi Rp. 53.751.000.000.

Penurunan dan kenaikan yang terjadi pada pembiayaan tidak diiringin dengan penurunan dan kenaikan pada dana pihak ketiga. Hal ini tidak sesuai dengan teori yang menyatakan semakin besar bank dapat menghimpun dana dari masyarakat, akan semakin besar kemungkinan bank tersebut dapat memberikan pembiayaan dan ini berarti semakin besar kemungkinan bank tersebut memperoleh pendapatan, sebaliknya semakin kecil dana yang dapat dihimpun semakin kecil pula pembiayaan yang diberikan, maka semakin kecil pula pendapatan bank.

\section{B. METODE}

Dalam penelitian ini dikumpulkan dari laporan keuangan publikasi PT. Bank Victoria Syariah. Data yang diakses peneliti yaitu laporan keuangan bulanan. Teknik analisis yang digunakan dalam penelitian ini adalah analisis regresi sederhana dapat dilihat pada tabel berikut ini:

$$
Y=\alpha+\alpha 1 X
$$

\section{HASIL DAN PEMBAHASAN}

Regresi linier sederhana yaitu suatu teknik untuk menentukan kolerasi antara variabel bebas dengan variable terikat. Adapun hasil pengujian regresi sederhana dapat dilihat pada tabel berikut ini:

Hasil Analisis Regresi Sederhana

Coefficientsa

\begin{tabular}{|ll|l|l|l|l|l|}
\hline \multirow{2}{*}{ Model } & \multicolumn{2}{|l|}{\begin{tabular}{l} 
Unstandardized \\
\multicolumn{2}{|l|}{ Coefficients }
\end{tabular}} & $\begin{array}{l}\text { Standardize } \\
\mathrm{d} \\
\text { Coefficients }\end{array}$ & T & Sig. \\
\cline { 2 - 5 } & B & Std. Error & Beta & & \\
\hline $\begin{array}{l}\text { (Consta } \\
\text { nt) }\end{array}$ & $\begin{array}{l}255291 . \\
491\end{array}$ & 81425.33 & 4 & 3.135 & .004 \\
& DPK & .426 & .061 & .767 & 6.971 & .000 \\
\hline
\end{tabular}

Berdasarkan hasil uji regresi sederhana diperoleh persamaan sebagai berikut:

$$
\begin{gathered}
Y=R p .255 .291,491+\alpha 1 \text { Rp.0.426.000.000 } \\
+e
\end{gathered}
$$

Persamaan regresi linear sederhan diatas dapat dijelaskan sebagai berikut:

a. Nilai konstanta sebesar Rp.255.291,491 menunjukkan jika dana pihak ketiga bernilai 0 atau konstanta, maka nilai Pembiayaan sebesar Rp. 255.291.491.

b. Koefisien dana pihak ketiga sebesar Rp.0.426.000.000 menunjukkan apabila dana pihak ketiga ditambah Rp.1.000.000 maka, Pembiayaan bertambah sebesar Rp. 
0,429.000.000. Koefisien bernilai positif artinya terjadi hubungan positif antara dana pihak ketiga dengan pembiayaan, semakin tinggi penghimpunan dana dari masyarakat, maka semakain tinggi bank menyalurkan pembiayaan kepada masyarakat.

Hipotesis dalam penelitian ini adalah: Jika thitung $<\mathrm{t}$ tabel maka Ha ditolak Jika thitung > ttabel maka Ha diterima

\section{Berdasarkan signifikansi:}

Jika signifikasi $<0,05$ maka Ha diterima

Jika signifikasi $>$ 0,05 maka Ha ditolak. Hasil Uji Parsial (Uji t)

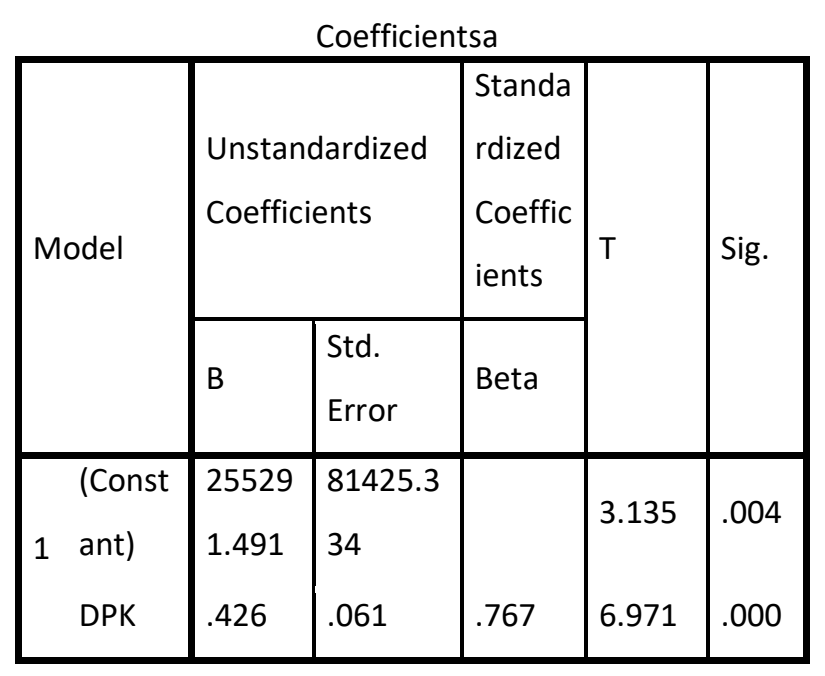

Tabel hasil Uji Parsial (Uji t) pada tabel diatas hasil pengujian signifikansi pengaruh variabel independen terhadap variabel dependen menggunakan Uji t diketahui bahwa ttabel dapat dilihat dari tabel statistik pada signifikan $0,05 / 2=0,025$, dengan derajat kebebasan $\mathrm{df}=\mathrm{n}-\mathrm{k}-1$ dimana $\mathrm{n}$ jumlah banyaknya sampel dan $k$ jumlah variabel independen (36-1-1) maka dapat diperoleh hasil ttabel sebesar 2,032. Sedangkan thitung 6,971. Artinya bahwa thitung > ttabel yaitu 6,971 > 2,032. Dengan nilai signifikansi dana pihak ketiga $(0,000<0.05)$, maka dapat disimpulkan Ha diterima. Artinya terdapat pengaruh yang signifikan antara dana pihak ketiga terhadap pembiayaan pada PT. Bank Victoria Syariah pada tahun 2016-2018.

Uji koefisien determinasi digunakan untuk mengetahui sejauh mana ketepatan atau kecocokan garis regresi yang terbentuk dalam mewakili kelompok data hasil observasi. Koefisien determinasi menggambarkan bagian dari variasi total yang dapat diterangkan oleh model. Semakin besar R2 (mendekati 1), maka ketepatannya dikatakan semakin baik.

Hasil Uji Koefisien Determinasi (R2) Model Summaryb

\begin{tabular}{|l|l|l|l|l|}
\hline Model & $R$ & $\begin{array}{l}R \\
\text { Square }\end{array}$ & $\begin{array}{l}\text { Adjusted } \\
\text { R Square }\end{array}$ & $\begin{array}{l}\text { Std. Error of } \\
\text { the Estimate }\end{array}$ \\
\hline 1 & $.767 a$ & .588 & .576 & 93974.506 \\
\hline
\end{tabular}

Berdasarkan tabel IV.6 di atas dapat diketahui besarnya R Square (R2) adalah 0,588 atau sama dengan $58,8 \%$ artinya bahwa variasi variabel dana pihak ketiga dapat menjelaskan variasi variabel pembiayaan sebesar $58,8 \%$ sedangkan sisanya $41,2 \%$ dijelaskan oleh variabel lainnya yang tidak ada dalam penelitian ini.

\section{PENUTUP}

1. Kesimpulan 
Penelitian ini bertujuan untuk melihat pengaruh dana pihak ketiga terhadap pembiayaan pada PT. Bank Victoria Syariah. Berdasarkan hasil penelitian, peneliti mengambil beberapa kesimpulan hasil uji koefisien determinasi $R$ square sebesar 0,588 atau $58,8 \%$ hal ini menunjukkan bahwa variabel dana pihak ketiga memberikan pengaruh sebesar $58,8 \%$ terhadap pembiayaan.

\section{Saran}

Penelitian ini merekomendasikan bagi peneliti selanjutnya agar bisa dikembangkan kedepannya dan tidak hanya focus pada variabel dana pihak ketiga karena masih banyak variabellain yang dapat mempengaruhi pembiayaan.

\section{DAFTAR PUSTAKA}

Abdul Rahman Ghazaly dkk, Fiqih Muamalat, Jakarta: Kencana, 2010.

Ascarya, Akad Dan Produk Bank Syariah, Jakarta: Rajawali Pers, 2013.

Adiwarman A. Karim, Bank Islam Analisis Fiqih dan Keuangan, Jakarta: Rajawali Pers, 2010.

Asmadi Alsa, Pendekatan Kuantitatif dan Kualitatif, Yogyakarta: Pustaka Pelajar, 2010.

Departemen Agama RI, al-Qur'an dan Terjemahannya, Jakarta: PT. Insan Media Pustaka, 2013.

Duwi Priyatno, SPSS 22 Pengolah Data Terpraktis, Yogyakarta: CV Andi Offset, 2014.
Dwi Suwiknyo, Kompilasi Tafsir Ayat-ayat Ekonomi Islam, Yogyakarta: Pustaka Pelajar, 2010.

Frianto Pandia, Manajemen Dana Dan Kesehatan Bank, Jakarta: Rineka Cipta, 2012.

Hasibuan Malayu S.P, Dasar-Dasar Perbankan, Jakarta: PT Bumi Aksara, 2011.

Hendi Suhendi, fiqh muamalah, Jakarta: PT Raja Grafindo Persada, 2014.

Ismail, Manajemen Perbankan Dan Teori Menuju Aplikasi, Jakarta: Kencana, 2010.

$\longrightarrow{ }^{-} \begin{gathered}\text { Perbankan Syariah, Jakarta: } \\ \text { Perdanamedia Group, 2011. }\end{gathered}$

Kasmir, Dasar-Dasar Perbankan, Jakarta: Pt Raja Grafindo Persada, 2008.

Lukman dendawijaya, Manajemen Perbankan, Jakarta: Ghalia Indonesia, 2010.

M. Nur Rianto, Dasar-Dasar Pemasaran Bank Syariah, Bandung: Alfabeta, 2012.

Mardiani, Fiqih Ekonomi Syariah, Jakarta: Kencana, 2012.

Muhammad, Metodologi Penelitian Ekonomi Islam, Jakarta: Raja Wali Perss, 2010.

Nanang Martono, Metode Penelitian Kuantitatif, Jakarta: Rajawali Perss, 2011.

Saifuddin Azwar, Metode Penelitian, Yogyakarta: Pustaka Pelajar, 2004.

Sugiyono, Metode Penelitian Bisnis, Bandung: Alfabet, 2005. 